\title{
Diagnosis of intestinal ascariasis in modern era
}

\author{
Satyajeet Roy, ${ }^{1}$ Paras Karmacharya, ${ }^{2}$ Madan Raj Aryal ${ }^{2}$
}

${ }^{1}$ Department of Internal Medicine, Cooper University Hospital, Cherry Hill, New Jersey, USA

${ }^{2}$ Department of Internal Medicine, Reading Health System, West Reading, Pennsylvania, USA

\section{Correspondence to}

Dr Paras Karmacharya, paraskarmacharya@gmail.com

Accepted 25 March 2014

\section{DESCRIPTION}

A 40-year-old woman presented with altered bowel movements, 10-pound weight loss and abdominal discomfort for 1 month. Prior to this, she had been on a week-long trip to Mexico. The patient's complete metabolic profile, complete blood count, serum amylase and lipase, urine analysis and culture and stool studies for white cell count, ova, parasite and culture were all either in the reference range or negative. An ultrasonography of the abdomen was normal. An axial CT scan of the abdomen with oral and intravenous radiocontrast material showed multiple tubular filling defects about $15 \mathrm{~cm}$ in length predominantly located in the jejunal lumen (figures 1-3), highly suggestive of intestinal parasites. She was treated with a dose of oral albendazole $400 \mathrm{mg}$. After 1 week, her symptoms improved and she reported passage of $15-20 \mathrm{~cm}$ long cream coloured cylindrical worms in her stool.

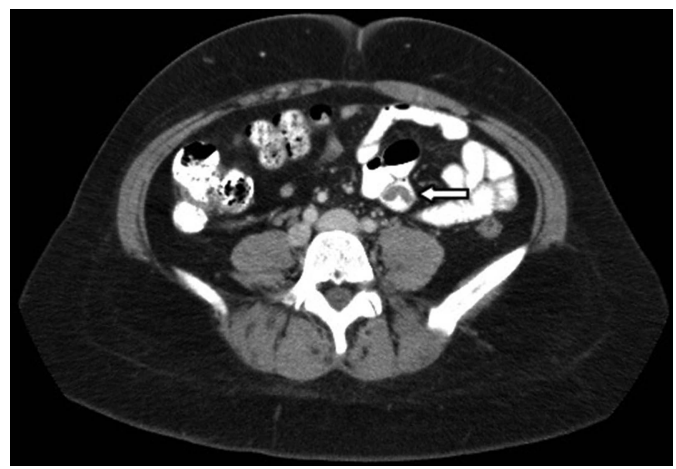

Figure 1 Axial section of contrast CT of the abdomen showing tubular filling defects in the jejunal lumen.

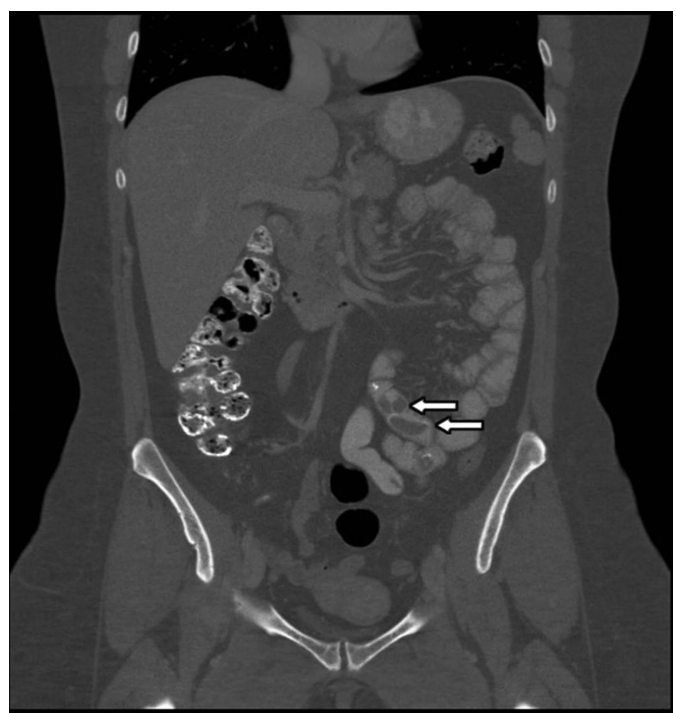

Figure 2 Coronal section of contrast CT of the abdomen showing tubular filling defects about $15 \mathrm{~cm}$ or more in length in the jejunal lumen.

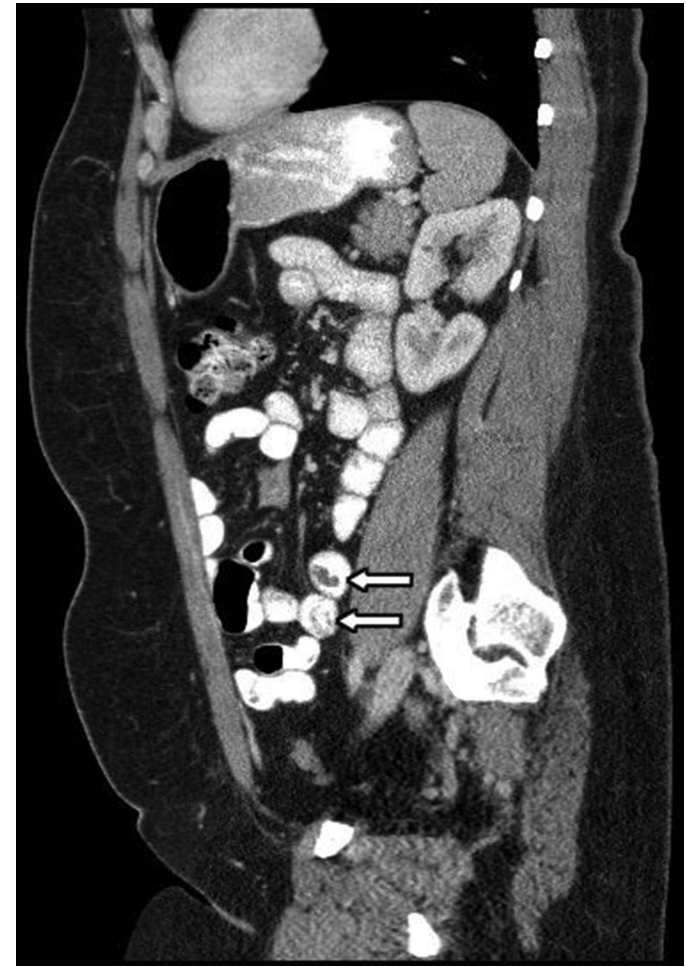

Figure 3 Sagittal section of contrast CT of the abdomen showing tubular filling defects in jejunum.

Ascariasis is caused by the parasitic roundworm, Ascaris lumbricoides and is uncommon in developed countries. Most patients are asymptomatic, hence it can be undetected for years until they develop some symptoms. ${ }^{1}{ }^{2}$ Diagnosis is usually made through a combination of blood counts showing marked leucocytosis with eosinophilia, stool studies and radiographic imaging. Complications can range from nutritional deficiency to obstruction of the bowel lumen, the bile or pancreatic duct, perforation, volvulus, intussusception, appendicitis, cholecystitis, biliary colic, cholangitis, hepatic abscess and pancreatitis depending on the site and severity of infestation. ${ }^{13}$ Antihelminthic therapy is usually sufficient except in few cases where surgical interventions might be needed. ${ }^{4}$

\section{Learning points}

- Intestinal ascariasis can present with nonspecific symptoms and signs.

- Diagnosis requires high index of suspicion and can be usually made through a combination of blood counts showing marked leucocytosis with eosinophilia, stool studies and radiographic imaging.

- Antihelminthic therapy is usually sufficient except in few cases where surgical interventions might be needed. 
Contributors SR wrote the initial manuscript and got the patient consent. PK and MRA edited the final manuscript and the images.

Competing interests None.

Patient consent Obtained.

Provenance and peer review Not commissioned; externally peer reviewed.

\section{REFERENCES}

1 Kanneganti K, Makker JS, Remy P. Ascaris lumbricoides: to expect the unexpected during a routine colonoscopy. Case Reports Med 2013;2013:579464.
2 Suzuki A, Yabushita Y, Takahashi H, et al. Gastrointestinal: ascariasis. J Gastroenterol Hepatol 2008;23:1770.

3 Zheng P-P, Wang B-Y, Wang F, et al. Esophageal space-occupying lesion caused by Ascaris lumbricoides. World J Gastroenterol 2012;18:1552-4.

4 Tay K-V, Teo J-Y. Education and imaging. Gastrointestinal: incidental findings of Ascaris lumbricoides in patient presenting with ureteric colic. J Gastroenterol Hepatol 2012:27:1127.

Copyright 2014 BMJ Publishing Group. All rights reserved. For permission to reuse any of this content visit http://group.bmj.com/group/rights-licensing/permissions.

BMJ Case Report Fellows may re-use this article for personal use and teaching without any further permission.

Become a Fellow of BMJ Case Reports today and you can:

- Submit as many cases as you like

- Enjoy fast sympathetic peer review and rapid publication of accepted articles

- Access all the published articles

- Re-use any of the published material for personal use and teaching without further permission

For information on Institutional Fellowships contact consortiasales@bmjgroup.com

Visit casereports.bmj.com for more articles like this and to become a Fellow 